University of Michigan Law School

University of Michigan Law School Scholarship Repository

\title{
Too Busy to Mind the Business? Monitoring by Directors with Multiple Board Appointments
}

\author{
Stephen P. Ferris \\ University of Missouri-Columbia \\ Murali Jagannathan \\ SUNY Binghamton \\ Adam C. Pritchard \\ University of Michigan Law School, acplaw@umich.edu
}

Available at: https://repository.law.umich.edu/articles/1555

Follow this and additional works at: https://repository.law.umich.edu/articles

Part of the Business Organizations Law Commons, and the Securities Law Commons

\section{Recommended Citation}

Pritchard, Adam C. "Too Busy to Mind the Business? Monitoring by Directors with Multiple Board Appointments." S. P. Ferris and M. Jagannathan, co-authors. J. Finance 58, no. 3 (2003): 1087-111.

This Article is brought to you for free and open access by the Faculty Scholarship at University of Michigan Law School Scholarship Repository. It has been accepted for inclusion in Articles by an authorized administrator of University of Michigan Law School Scholarship Repository. For more information, please contact mlaw.repository@umich.edu. 


\title{
Too Busy to Mind the Business? Monitoring by Directors with Multiple Board Appointments
}

\author{
STEPHEN P. FERRIS, MURALI JAGANNATHAN, and A.C. PRITCHARD*
}

\begin{abstract}
We examine the number of external appointments held by corporate directors. Directors who serve larger firms and sit on larger boards are more likely to attract directorships. Consistent with Fama and Jensen (1983), we find that firm performance has a positive effect on the number of appointments held by a director. We find no evidence that multiple directors shirk their responsibilities to serve on board committees. We do not find that multiple directors are associated with a greater likelihood of securities fraud litigation. We conclude that the evidence does not support calls for limits on directorships held by an individual.
\end{abstract}

INSTITUTIONAL INVESTORS AND SHAREHOLDER ACTIVISTS criticize firms for appointing directors who hold directorships in multiple companies, contending that such directors are incapable of effectively monitoring the management of so many firms. Informed observers such as Chancellor William Allen (1992) of the Delaware Court of Chancery argue that "effective monitoring requires a commitment of time and resources ... The demands of the position, if properly understood, are inconsistent in my opinion, with service on an impressively long list of boards (p. 457)."

Corporate governance activists echo these criticisms and propose specific limits to deal with the perceived problem. The Council of Institutional Investors (1998) argues that in the absence of unusual and highly specific circumstances, directors with full-time jobs should not serve on more than two other boards. The National Association of Corporate Directors (1996) is more lenient, suggesting that directors with full-time positions should not serve on more than three or four other boards. The Business Roundtable (1997), by contrast, believes that limits on the number of directorships are ill advised.

Directors themselves disagree over the issue of multiple directorships. The most commonly shared complaint among directors, according to Lipton and

*Ferris is from the College of Business, University of Missouri-Columbia, Jagannathan is from the School of Management, Binghamton University-SUNY, and Pritchard is from the Law School, University of Michigan. This paper has benefited from the helpful comments and suggestions of Merritt Fox, Richard Lempert, Anil Makhija, Ronald Mann, Mark West, seminar participants at the University of Michigan, University of Missouri-Columbia, Vanderbilt University, and the American Law and Economics Association and the Financial Management Association annual meetings. Pritchard acknowledges financial support from the Cook Fund of the University of the Michigan Law School. The authors alone are responsible for this work and any errors or omissions. 
Lorsch (1992), is insufficient time for the discharge of their professional responsibilities. A survey of directors of Fortune 500 companies by Korn/Ferry International (1998) finds that many directors believe too many board appointments place an excessive burden on a director. Fifty-six percent of outside directors report that they declined an invitation to serve on an additional board, with the majority citing a lack of time as their reason for refusal.These directors evidently believe that too many board assignments might dissipate their time and attention, thereby undermining their ability to monitor management. That same study also finds that an overwhelming majority of directors believe that CEOs and other inside directors should be limited in the number of boards to which they are appointed, but directors were evenly divided on whether limits should be placed on outside directors. Thus, whether holding multiple directorships impairs an individual director's ability to monitor management has become a controversial topic that has spawned proposals for governance reform.

Despite this controversy, very little research has been done concerning the effect of multiple directorships on corporate performance. Our study tests the hypothesis that directors who serve on multiple boards become so busy that they cannot monitor management adequately. What we call the Busyness Hypothesis of corporate directorships postulates that serving on multiple boards overcommits an individual. As a consequence, such individuals shirk their responsibilities as directors. For example, overcommitted directors might serve less frequently on important board committees such as the audit or the compensation committees. If boards play an important role in firm performance, the implication of the Busyness Hypothesis is that the presence of multiple directors on a firm's board reduces oversight of management and, as a result, the firm's market value. Additionally, reduced monitoring by these busy directors might exacerbate other forms of agency costs, such as increased litigation exposure for the firm.

Our principal findings are as follows. Examining the market for directors, we find that the past performance of firms for which an individual serves as a director correlates with the number of directorships subsequently held by that individual, a result we call the reputation effect. When we test the Busyness Hypothesis in a multivariate framework, we find no evidence that multiple board appointments harm subsequent firm performance.

Additional tests confirm this result. An event study of firms announcing the appointment of a multiple director finds that firms announcing the appointment of a multiple director for the first time experience significantly positive abnormal returns. Comparing committee service by multiple directors with that of nonmultiple directors, we find that multiple directors serve on more committees and attend more committee meetings. Such a result is inconsistent with shirking by multiple directors. Finally, we find no relation between the number of directorships and the likelihood of securities fraud litigation against the firm. Overall, we conclude that our findings do not support the Busyness Hypothesis.

We organize this study into six sections. In Section I, we discuss the prior literature relating to the market for directors and multiple directorships. In Section II, we discuss our data and methods, and we describe the characteristics of 
multiple directors in Section III. In Section IV, we examine the relation between the firm's previous performance and the number of directorships held by its directors as well as the likelihood that a director will add an additional board appointment. Section V presents the results of our tests of the Busyness Hypothesis. Section VI concludes with a brief summary.

\section{The Market for Directorships and the Influence of Directors on Firm Performance}

Some scholars argue that the market for directors serves shareholder interests. Fama and Jensen (1983) contend that multiple board appointments can signal director quality. The appointment to numerous boards might be the result of the superior performance enjoyed earlier by the firm for which the individual serves as a director or as an executive. If the market for directors is linked to corporate performance, firm success can generate additional offers of board employment. Following Fama and Jensen, Gilson (1990), Kaplan and Reishus (1990), and Vafeas (1999) suggest that the number of directorships held by a director might proxy for reputational capital, with such individuals viewed as high quality directors. Moreover, service on multiple boards can provide a director with a greater diversity of experience.

Related research shows that poor performance is punished in the market for directors. Gilson (1990) finds that outside directors who leave the boards of financially distressed firms hold approximately one-third fewer directorships three years after their departure. Kaplan and Reishus (1990) find that top executives of firms that reduce dividends are 50 percent less likely to obtain additional directorships. Similarly, Brickley, Linck, and Coles (1999) report that the number of board seats held by retiring CEOs is related to firm performance prior to their retirement. Shivdasani (1993) observes that outside directors of firms that are the targets of hostile bids are likely to hold fewer directorships than directors of nontarget firms. If firms become targets due to poor performance, Shivdasani's findings lend additional support to Fama and Jensen's (1983) argument. In sum, these studies suggest that directors of underperforming firms suffer from tarnished reputations in the market for directors.

Other factors might influence the number of directorships held by an individual. Booth and Deli (1995) argue that larger firms have wider contracting environments, requiring negotiations with more parties. The increased level of business transactions resulting from these contracts can create a greater opportunity for offers of additional board memberships. Multiple directorships permit the firm to use its directors to form or solidify advantageous contracting relations with other firms, such as important suppliers or customers. An alternative argument for a relation between firm size and the number of directorships held per director is that directors of large firms might be attractive as candidates for other boards because of the networking contacts they represent to these firms. In addition, directors of large firms might be perceived as more skilled because of the size and complexity of the operations they oversee. 
Certain scholars are more skeptical that the market for directors serves shareholder interests. Core, Holthausen, and Larcker (1999) and Shivdasani and Yermack (1999) suggest that directors can become overcommitted when serving on multiple boards, rendering them unable to provide meaningful managerial monitoring. Managers subject to lax monitoring might be able to impose greater agency costs on the firm, with a consequent reduction in firm performance and value. The empirical work of these scholars offers some support to the Busyness Hypothesis.

Core et al. (1999) report that the presence of directors holding multiple appointments correlates with excess CEO compensation, implying that such directors serve as an inadequate check on management. Shivdasani and Yermack (1999) also provide evidence that questions the independence of directors who hold multiple appointments. They report that directors with multiple directorships are more likely to be chosen for an additional board seat if the CEO of the firm is involved in the director selection process. This evidence suggests that directors holding multiple appointments cater to CEOs, implying that their monitoring of management does little to reduce agency costs. If this is correct, the market for directors might be geared toward ensuring a compliant board for the $\mathrm{CEO}$, rather than representing shareholder interests.

Other evidence, however, suggests that multiple directors are associated with firm success. Miwa and Ramseyer (2000) find that the presence of directors holding multiple directorships was strongly related to firm performance in the cotton spinning industry in Japan during the first decade of the 20th century. Cotter, Shivdasani, and Zenner (1997) document that shareholders receive larger premiums in tender offers when the board includes multiple directors. Finally, Brown and Maloney (1999) find that firms enjoy superior returns from acquisitions when they have directors who hold multiple directorships. These studies suggest that multiple directorships are consistent with shareholder interests. Whether the results of these studies can be generalized, however, is open to question, given their specialized settings and circumstances.

\section{Data and Methods}

\section{A. Sample Construction}

The primary sample that we examine in this study consists of those firms on COMPUSTAT with at least $\$ 100$ million in total assets at the beginning of 1995 . We are able to obtain proxy statements for 2,002 of these firms, from which we obtain directors' names, age, individual director's equity ownership, board ownership, board tenure, professional affiliation, and independence. We obtain directors' names, age, and the board's ownership for an additional 1,188 firms from Compact Disclosure. This produces a final sample of 3,190 firms. The various measures of directorships held by individual directors used in this study only include appointments to the boards of our sample firms. This constraint is necessary to allow us to examine firm-level accounting and financial data, which we obtain 
from COMPUSTAT. The Center for Research in Security Prices (CRSP) database provides equity return time-series data.

\section{B. Measurement of Multiple Directorships}

For each firm, we calculate several different measures of multiple directorships. Each measure is calculated at the level of the firm's board, thereby allowing us to match firm-level data with these measures of multiple directorships. The first, directorships per director, measures, for a given firm, the average number of sample firm directorships held by the directors of that firm. The second measure is the maximum number of directorships held by any one member of a firm's board. Our third measure is the percentage of directors on a board who hold three or more directorships.

We calculate two additional measures of multiple directorships to provide a more particularized assessment of the effect of director business on the firm. To focus on external monitoring, our fourth measure is the average number of directorships held by the outside directors ${ }^{1}$ of a given firm. Because the potential distraction of multiple directorships might be more of a problem for firms that employ these potentially overstretched individuals as officers, our final measure is the maximum number of directorships held by any executive of the firm (in practice, usually the CEO). ${ }^{2}$ We include board chairs as executives in calculating this measure because many chairmen who do not hold titles as officers nonetheless receive salaries, suggesting that they are full-time employees of the firm.

\section{Characteristics of Directors Holding Multiple Appointments}

\section{A. The Incidence of Multiple Directorships}

In Panel A of Table I, we report data regarding the frequency of multiple board directorships for our sample in $1995 .{ }^{3}$ We immediately observe that multiple directorships are not the norm. Only 16 percent of all directors hold two or more board seats. Even less common, at approximately 6 percent of the sample of total directorships, are directors holding three or more directorships - the limit proposed by the Council of Institutional Investors. For those directors (hereafter "multiple directors"), the directorships they hold are heavily skewed toward the largest firms in our sample. We find that multiple directors hold approximately half of their directorships in Forbes 500 firms. We conclude that multiple directorships are primarily a large-firm phenomenon.

\footnotetext{
${ }^{1}$ We include in this category all directors who are not currently employed by the firm.

${ }^{2}$ In calculating variables related to executives, we take data related to the executive with the highest number of directorships. In the event of a tie between two or more executives, we focus on the highest ranking, that is, chair over CEO, CEO over CFO, and so forth. Because the CEO is most commonly the individual with the greatest number of directorships, we refer to the variables related to this executive as "CEO" for ease of exposition.

${ }^{3}$ These statistics are calculated at the level of the individual director, rather than the board level.
} 
Table I

\section{Patterns in the Number of Directorships Held by Directors}

Panel A presents the numbers of directors for our sample firms, classified by the number of directorships held. The sample consists of those firms on Compustat with at least $\$ 100$ million in total assets at the beginning of 1995 for which we have director data from either corporate proxy statements or Compact Disclosure. We calculate the number of directorships held for any individual director using only directorships held in this sample of firms. Panel B contains the mean (median) for various measures of directorships held. Directorships per director is estimated as the total number of directorships held by the directors of a board divided by board size. The maximum number of directorships held is the largest number of total directorships held by any director on a specific board. The percentage of directors holding three or more directorships is the number of directors holding three or more total appointments divided by board size. Directorship per outside director is the mean number of directorships held by the outside directors of the firm. This variable assumes a value of zero if the firm does not have any outside directors on its board. The maximum number of directorships held by an executive is the largest number of total directorships held by a director on the board who is also an executive of the firm (including the chairman of the board).

\begin{tabular}{lcccc}
\hline \multicolumn{4}{c}{ Panel A: Directors by Number of Directorships } & \\
\hline Directorships & & & & Fraction of \\
Held & Number of & Fraction of & Fraction of & $\begin{array}{c}\text { Directorships in } \\
\text { Forbes 500 firms }\end{array}$ \\
\hline 1 & Directors & Directors & Total Directorships & 18.51 \\
2 & 19,978 & 84.39 & 67.60 & 33.74 \\
3 & 2,383 & 10.07 & 16.13 & 46.59 \\
4 & 767 & 3.24 & 7.79 & 50.71 \\
5 & 351 & 1.48 & 4.75 & 59.48 \\
6 & 115 & 0.49 & 1.95 & 49.65 \\
7 & 47 & 0.20 & 0.95 & 59.66 \\
8 & 17 & 0.07 & 0.40 & 68.75 \\
9 & 10 & 0.04 & 0.27 & 37.04 \\
10 & 3 & 0.01 & 0.09 & 0.00 \\
11 & 0 & 0.00 & 0.00 & 63.64 \\
Total directors & 2 & 0.01 & 0.07 & 5,979 \\
Total directorships & 29,673 & & & 7,721 \\
Number of firms & 3,190 & & & 653 \\
\hline
\end{tabular}

Panel B: Means (Medians) for Alternative Measures of Multiple Directorships

\begin{tabular}{lcccc}
\hline $\begin{array}{l}\text { Directorships } \\
\text { per Director }\end{array}$ & $\begin{array}{c}\text { Maximum Number } \\
\text { of Directorships } \\
\text { Held }\end{array}$ & $\begin{array}{c}\text { Percentage of } \\
\text { Directors with Three } \\
\text { or More Directorships }\end{array}$ & $\begin{array}{c}\text { Directorships } \\
\text { per Outside } \\
\text { Director }\end{array}$ & $\begin{array}{c}\text { Maximum Number } \\
\text { of Directorships } \\
\text { Held by an Executive }\end{array}$ \\
\hline 1.600 & 3.12 & 14.97 & 1.89 & 1.91 \\
$(1.40)$ & $(3)$ & $(9.09)$ & $(1.70)$ & $(1)$ \\
\hline
\end{tabular}

In Panel B, we present alternative measures of multiple directorships. The mean (median) of directorships per director is 1.60 (1.40), the maximum number of directorships held by any director of a firm has a mean (median) of 3.12 (3.00), while the percentage of directors holding three or more directorships has a mean 
(median) of 14.97 percent (9.09 percent). ${ }^{4}$ When we focus on the outside directors and the executives who serve on the board, we find that the means are quite similar for the two categories (1.89 directorships per outside director, 1.91 for the maximum number of directorships held by an executive), although the median is higher for the outside directors measure (1.70 and 1, respectively).

\section{B. Professional Affiliations of Directors}

We examine the professional affiliations of directors in Table II. We collect this demographic data from corporate proxy statements. Not surprisingly, current and former corporate executives are the largest source of directors, accounting for over 56 percent of the directors with one or two directorships and 62 percent of the multiple directors. Executives from large Forbes 500 firms are much more likely to be multiple directors than their counterparts from smaller firms, suggesting that the experience of running a major company leads to more offers of directorships than experience running smaller firms. Among other groups, venture capitalists stand out as frequent multiple directors, perhaps reflecting ownership interests or perceived expertise in firm monitoring.

\section{Director and Firm Characteristics}

In Table III, we continue our univariate analysis of the characteristics of multiple board memberships. We compare firms with multiple directors with firms whose directors hold only one or two directorships.

The firm characteristics that we compare include several sets of possible determinants of the number of board appointments. The first set focuses on the demands imposed by directorships: Whether directorships are held in a single industry ${ }^{5}$ and whether directorships are held in large firms which we proxy by inclusion on the Forbes 500 list. The second set includes important financial characteristics: firm size (total assets), the firm's growth potential (market-to-book ratio), and profitability (operating margin). The final set includes director and board characteristics: average age of the directors, equity ownership by the entire board, equity ownership by the outside directors, board size, and the percentage of outside directors.

\section{C.1. Financial Characteristics}

We find that multiple directorships are associated with larger firms as measured by total assets at the beginning of 1995 . This result is consistent with the view that larger firms have more external contracting relationships than smaller companies and hence greater opportunity for gain from the well-bonded relationships likely to result from external directorships. It is also consistent, however,

\footnotetext{
${ }^{4}$ Although not reported separately, we find that the correlation between these three measures is high (ranging from 0.79 to 0.93 ). Given such a high correlation, our alternative measures of multiple directorships unsurprisingly produce similar results. Accordingly, we tabulate only the directorships per director measure for our multivariate regressions.

${ }^{5}$ For individuals holding three or more directorships, industry directors are defined as holding at least 50 percent of their directorships within the same two-digit SIC code.
} 


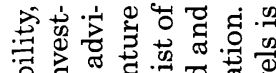

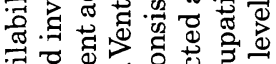

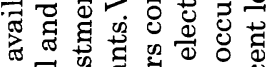

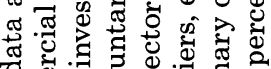
of पू 명 记 कू की

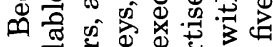
흥 हึँ 平䓃

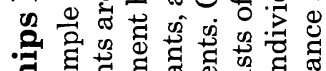

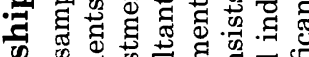
。 छ छ

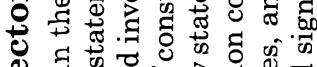

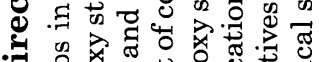

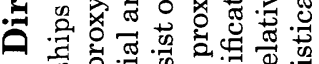

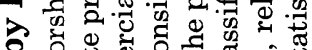
की

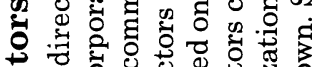
0 \& 8 .

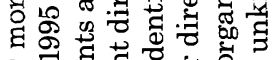

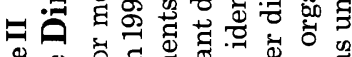

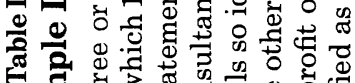
दु

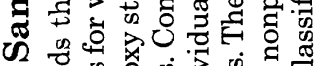

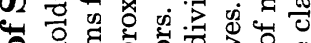
- द्वे 苛 ब

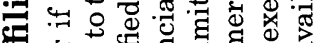

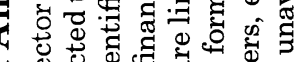
万ٓ.

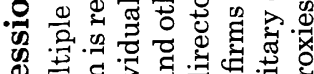

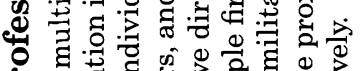

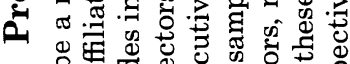

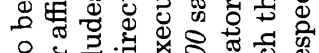

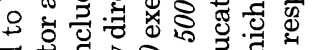
政

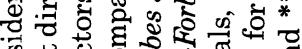

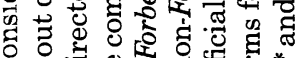

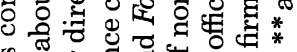
里

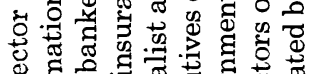

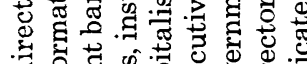

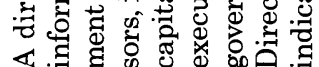

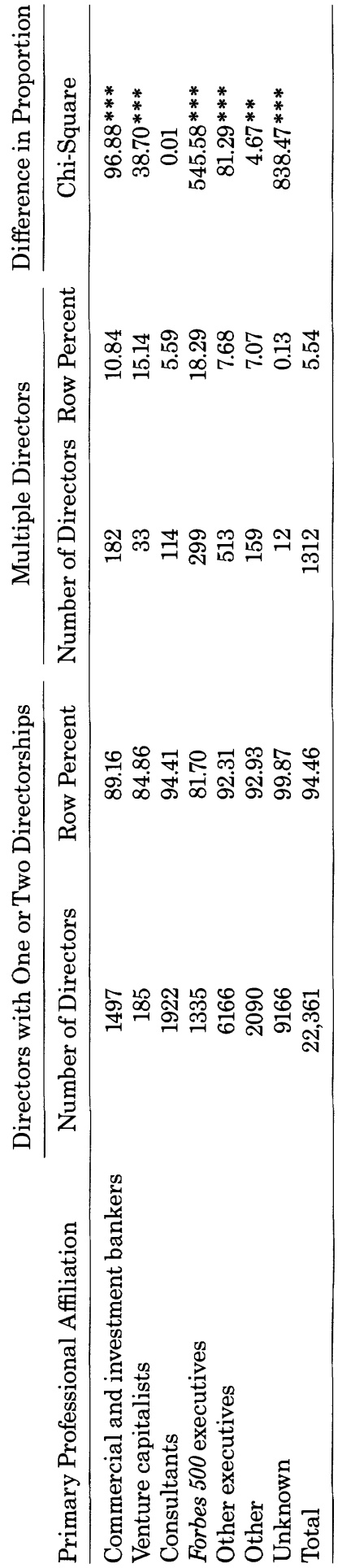




\section{Table III \\ Comparative Characteristics of Firms with and without Multiple Directors}

Table III compares the means (medians) of firm and board characteristics of firms between firms with and without multiple directors. A director is considered a multiple director if he/she holds three or more directorships in the sample firms. All financial variables are calculated as of fiscal year-end 1994. Industry directors are defined as individuals holding three or more directorships with at least 50 percent of their directorships held in firms having the same two-digit SIC code. Directorships per director in Forbes 500 firms is the mean number of directorships held by a director in Forbes 500 firms. The market-to-book ratio is the ratio of the market value of firm equity plus the book value of preferred stock plus the book value of debt to the total value of assets. Operating margin is annual operating income standardized by total assets. Total assets are those reported by Compustat at year-end. Corporate governance data is obtained from the firms' proxies for the 1995 proxy season. Board size is firm's total number of directors, while board ownership is the percent of the firm's total outstanding equity held by the firm's directors. Outside director ownership is percent of total equity held by outside directors. Thirty firms with boards of three or less are not included in this analysis due to incomplete information. Statistical significance at the one percent level is indicated by $* * *$.

\begin{tabular}{lccc}
\hline & $\begin{array}{c}\text { Firms without } \\
\text { a Multiple } \\
\text { Director }\end{array}$ & $\begin{array}{c}\text { Firms with } \\
\text { a Multiple } \\
\text { Director }\end{array}$ & $\begin{array}{c}t \text {-statistic } \\
\text { (Wilcoxon } z \text { ) }\end{array}$ \\
Characteristic & 1449 & 1711 & \\
Number of firms & & 291 & \\
Number of firms with industry directors & 0.82 & 0.80 & $34.44^{* * *}$ \\
Directorships per director in Forbes 500 firms & $(0)$ & $(0.44)$ & $(38.1)^{* * *}$ \\
& 832.12 & 5214.89 & $10.23^{* * *}$ \\
Total assets & $(306.39)$ & $(793.12)$ & $(18.61)^{* * *}$ \\
& 1.87 & 2.43 & $9.91^{* * *}$ \\
Market-to-book & $(1.47)$ & $(2.02)$ & $(12.99)^{* * *}$ \\
& 9.61 & 14.56 & $12.12^{* * *}$ \\
Operating margin & $(5.13)$ & $(13.87)$ & $(14.66)^{* * *}$ \\
& 57.01 & 58.07 & $5.79^{* * *}$ \\
Average Age & $(57.28)$ & $(58.59)$ & $(5.74)^{* * *}$ \\
& 23.59 & 17.86 & $7.03^{* * *}$ \\
Board Ownership & $(16.29)$ & $(7.40)$ & $(11.41)^{* * *}$ \\
& 5.84 & 5.42 & 0.60 \\
Outside Directors Ownership & $(1.08)$ & $(0.64)$ & $3.42^{* * *}$ \\
& 8.51 & 10.37 & $14.95^{* * *}$ \\
Board Size & $(8)$ & $(10)$ & $(15.94)^{* * *}$ \\
& 17.61 & 32.84 & $17.62^{* * *}$ \\
Percent Outside Directors & $(16.67)$ & $(33.33)$ & $(15.48)^{* * *}$ \\
& & & \\
\hline
\end{tabular}

with the view that directors and executives of large firms are perceived to possess desirable abilities resulting from their oversight of a major corporation.

To analyze firm value, we employ both market and accounting-based measures. We use the firm's market-to-book ratio and the firm's operating profit margin. We explicitly include an accounting based measure of performance because managers are often provided incentives to respond to accounting figures rather than more conventional market benchmarks (Bhagat, Brickley, and Lease (1985), Gaver, Gaver, and Battistel (1992), and Kumar and Sopariwala (1992)). 
The differences between firms on these measures are generally statistically significant. Most notably, firms with multiple directors are more highly valued as measured by the market-to-book ratio. Firms with multiple directors also enjoy higher operating profit margins. ${ }^{6}$

Overall, we believe that these comparisons are consistent with the contention of Fama and Jensen (1983) that multiple directorships relate positively to firm performance. These simple comparisons do not, however, indicate the direction of causation between firm performance and a board appointment. If the market for directors works efficiently, the best directors should receive the greatest number of offers to serve as a director. These quality directors might generate higher levels of performance from the firm. Alternatively, Bhagat and Black (1999) argue that more successful firms are able to attract directors who serve on multiple boards. We explore the nature of this relation between multiple directorships and firm performance in greater detail in Sections IV and V.

\section{C.2. Corporate Governance Characteristics and Agency Costs}

Given the fees and prerogatives associated with board membership, an agency cost view of multiple board affiliations hypothesizes them as a form of perquisite consumption. The Busyness Hypothesis implies that multiple board memberships might reflect organizational slack due to agency conflict: Directors overcommit themselves at the expense of shareholders because they enjoy the prestige and fees associated with sitting on numerous boards. Reduced monitoring by such directors allows managers to impose greater agency costs on shareholders.

Directors who are older might pose a last-period risk. Individuals close to retirement age might seek to maximize their current incomes by accepting excessive commitments. Alternatively, individuals nearing retirement age might view multiple directorships as an interesting and lucrative part-time job for their retirement years. Either motivation could lead to poor performance in their current employment. That poor performance is unlikely to be sanctioned by job termination or reductions in salary because of the proximity to retirement. Brickley et al. (1999), however, find that the number of board seats held by retiring CEOs is related to firm performance prior to their retirement. We find that directors are, on average, older for firms with multiple directors, suggesting that the final period problem might be an issue. The magnitude of the difference, however, while statistically significant, is only one year.

Equity ownership by the board and executives might align their interests more closely with those of shareholders. For example, Bhagat, Carey, and Elson (1999) find that outside directors holding greater equity are more likely to replace the

\footnotetext{
${ }^{6}$ We obtain similar results (untabulated) when we compare firms that have executives who are multiple directors with firms lacking an executive who serves on multiple boards. For firms with executives who are multiple directors, however, the mean profitability is lower, but median profitability is statistically indistinguishable from that for firms without such executives. We also obtain evidence suggesting that firms with multiple directors enjoy higher market-to-book ratios.
} 
CEO of a poorly performing company. If directors accept appointments to additional boards as a form of perquisite consumption, then we should observe lower equity ownership by directors for firms with multiple directors. Equity holding directors should be reluctant to accept excessive directorships since impaired monitoring would impose direct costs in the form of lower prices for their equity.

We find that firms with multiple directors have lower overall board ownership, as well as lower ownership by outside directors. These findings are consistent with the argument that directors view additional board memberships as perquisites and are deterred from accepting additional directorships when they face greater personal costs from such consumption. They are also consistent, however, with the view that different directors might bring different skills to the directorship role. Some directors can be good monitors because they have invested their own capital in the enterprise, while others are effective monitors because of their experience. ${ }^{7}$ While these differences might reflect agency costs, they might also be a statistical artifact: Multiple directors serve on the boards of larger firms, so personal wealth constraints might preclude their ability to gain substantial ownership in those firms (especially considering their service on the boards of multiple firms).

Lack of monitoring might also be reflected in board size. Yermack (1996) and Eisenberg, Sundgren, and Wells (1997) argue that large boards are often unwieldy, while smaller boards can monitor managers more effectively. Table III documents larger board size for firms with multiple directors. This finding supports the view that multiple directorships can be a form of perquisite consumption, a result consistent with the Busyness Hypothesis. Alternatively, firms with larger boards present greater opportunities for board members to make connections leading to additional invitations to serve on other boards. If this view is correct, directors serving on larger boards are more likely to hold more directorships. As with board ownership, however, our findings might simply reflect the fact that holding multiple directorships is a large firm phenomenon.

Finally, less independent boards might reflect agency costs. Boards with a greater percentage of outside directors might be able to exercise greater monitoring and demand more accountability from managers. The relation of independence to performance is not clear. Bhagat and Black (2001) find no correlation between board independence and firm performance.

In sum, our univariate comparisons suggest that multiple directorships are generally consistent with our conjectures regarding firm size and profitability. But several features of corporate governance for firms with multiple directors suggest the presence of agency costs. Such an interpretation is consistent with the arguments of the Council of Institutional Investors and other corporate governance activists. These characteristics, however, also relate to firm size and multiple directorships are a large firm phenomenon. We explore this tension in greater detail in the next sections with a multivariate analysis.

\footnotetext{
${ }^{7}$ We also find (in untabulated results) that executives who are multiple directors hold a smaller percentage of equity in their firms than executives who are not multiple directors.
} 


\section{The Effect of Firm Performance on the Number of Directorships}

The univariate comparisons for the operating margin and the market-to-book ratio discussed in the previous section suggest that there might be a positive relation between multiple directorships and firm performance. To test whether firm performance influences the number of directorships as posited by Fama and Jensen (1983), we estimate a series of multivariate logistic regressions. These regressions use director data, thus allowing us to examine the determinants of a directorship at the level of individual director. We first examine the influence of firm performance on the number of directorships held by the set of all directors in our sample. We then separately examine the effect of firm performance on the number of directorships held by executives.

We include a number of control variables that might affect the individual's desire to serve on more boards and influence the individual's attractiveness as a director. Previous firm performance is estimated as the average of the mean operating margin over the period 1993 through 1995 for all firms with which the director was affiliated. For the analysis of executives who are directors, we use the mean operating margin over the period 1993 through 1995 for the firm that is their full-time employer because this is likely to be the most salient indicator of their business acumen. Average ownership in the firms reflects the personal cost to the director of having his attentions diluted with the addition of more boards. For executives, we use their ownership in the firm that is their full-time employer. Age is a proxy for the director's experience as well as the energy that an individual might have for the demands of board service. Surveys report that lack of time is the reason most often cited for declining offers of board seats. Average firm size is a proxy for the intensity of monitoring required of the director. Although larger firms are likely to demand additional effort, they might also send a more positive signal of a director's skill as a monitor. For our regressions examining the acquisition of additional board appointments, we include the number of boards the director sat on in 1994 as a proxy for existing demands on the individual's time.

We present our findings in Table IV. Panel A contains our findings for the determinants of the total number of directorships held by an individual director ${ }^{8}$ while in Panel B we examine what factors determine whether an individual gains an additional board appointment. We find evidence consistent with a reputational effect in the market för directors. Prior firm performance has a positive coefficient and is strongly significant as a determinant of the number of directorships held in both sets of regressions; it is also strongly statistically significant for directors receiving new appointments. Overall, these results imply that the firm's previous performance influences the number of seats that a director holds as well as the likelihood of an appointment to a new board. In aggregate, these results indicate that the market for directorships rewards good monitoring insofar as that monitoring can be associated with strong financial performance.

\footnotetext{
${ }^{8}$ All directors holding more than five directorships are coded as holding six for purposes of this regression.
} 


\section{Table IV}

\section{The Effect of Firm Performance on the Number of Directorships}

Panel A reports the results of an ordered logistic regression examining the determinants of the number of directorships held by the sample of all directors and separately for executives who are directors. If the number of directorships exceeds five, then the number of directorships is set to six. Panel B reports the results of a binomial regression in which the dependent variable is whether the individual received an additional directorship between 1994 and 1995. Total assets are those reported by Compustat at year-end. Operating margin is the firm's operating income standardized by total assets. Ownership is equity ownership of the board of directors. For directors these variables are the mean for all firms upon whose boards they sit. CEO is defined as the executive with the greatest number of directorships (usually the CEO). Operating margin for CEO firms is for the firm that is the CEO's full-time employer. CEO ownership is the percent of total equity held by the director with the greatest number of directorships, usually the CEO. Age is the chronological age of the individual. Current directorships is the number of directorships held by the individual as of 1994 . Statistical significance at the 10,5 , and 1 percent levels is indicated by ${ }^{*}, * *$, and ${ }^{* * *}$, respectively.

\begin{tabular}{|c|c|c|}
\hline Variable & All Directors & Executives \\
\hline \multicolumn{3}{|c|}{ Panel A: Determinants of Directorships } \\
\hline Intercept 1 & $-4.810 * * *$ & $-5.461^{* * *}$ \\
\hline Intercept 2 & $-6.046 * * *$ & $-6.741 * * *$ \\
\hline Intercept 3 & $-7.001 * * *$ & $-7.701 * * *$ \\
\hline Intercept 4 & $-8.077 * * *$ & $-8.818 * * *$ \\
\hline Intercept 5 & $-8.983^{* * *}$ & $-9.960 * * *$ \\
\hline Log of average total assets 95 & $0.423^{* * *}$ & \\
\hline Log of total assets for CEO firm 95 & & $-0.006 * *$ \\
\hline Average operating margin $_{93-95}$ & $1.417 * * *$ & \\
\hline Operating margin for CEO firm ${ }_{93-95}$ & & $0.136 * * *$ \\
\hline Average director ownership & 0 & \\
\hline CEO ownership & & $0.369 * * *$ \\
\hline Age & $0.008 * * *$ & $0.049 * * *$ \\
\hline \multicolumn{3}{|c|}{ Panel B: Determinants of Additional Directorships } \\
\hline Intercept & $1.553^{* * *}$ & -18.599 \\
\hline Log of average total assets 95 & $0.195 * * *$ & $0.201 * *$ \\
\hline Log of total assets for CEO firm 95 & & \\
\hline Average operating margin $_{93-95}$ & $2.967 * * *$ & $2.041 *$ \\
\hline Operating margin for CEO firm $_{93-95}$ & & \\
\hline Average director ownership & 0.003 & -0.036 \\
\hline CEO ownership & & \\
\hline Current directorships & $-1.009 * * *$ & 16.284 \\
\hline Age & $-0.048^{* * *}$ & $-0.030 *$ \\
\hline
\end{tabular}

We find that age has a significant positive coefficient in the regression for the number of directorships held. Age is significant and negative, however, in Panel B's regression for additional directorships, suggesting that older directors (who already hold a greater number of directorships) are either less interested in additional directorships or less attractive candidates. The number of directorships also has a statistically significant negative coefficient in the directors' regression for the appointment to new boards, suggesting that firms are reluctant 
to appoint directors who might overextend themselves (or directors are reluctant to accept an additional appointment that can overextend them). Firm size is consistently positive and statistically significant, reinforcing our earlier finding that multiple directorships are a large-firm phenomenon.

In sum, our results suggest that the previous performance of firms follows directors and affects both the number of directorships they currently hold and their ability to attract additional board appointments. We interpret such a result as consistent with the presence of a reputational effect in the market for directors, as posited by Fama and Jensen (1983). Such an effect should serve as a further incentive for directors to provide satisfactory monitoring.

\section{Empirical Tests of the Busyness Hypothesis}

The multivariate analysis of Section IV reports a relation between firm performance and the number of directorships an individual subsequently holds. The $\mathrm{Bu}-$ syness Hypothesis, however, predicts that multiple directorships will lead to poorer firm performance in the future because they dilute the quality of managerial monitoring.

In this section, we test the Busyness Hypothesis through a series of empirical tests. We first examine the relation between multiple directorships and subsequent firm performance in a multivariate framework. We also perform an event study of the response to the appointment of a multiple director to a firm's board. We then examine whether multiple directors do, in fact, provide a level of monitoring comparable to that of directors holding only one or two board appointments by investigating their level of committee service. Finally, we evaluate the effectiveness of the monitoring provided by multiple directors by using as a measure of director effectiveness the incidence of securities fraud litigation against the firm over a three-year sample period. We estimate a logistic regression to determine whether firms with multiple directors are sued more often than firms without multiple directors.

\section{A. A Multivariate Analysis of Multiple Directorships and Firm Performance}

Several findings from Table III suggest that the presence of multiple directorships might generate higher agency costs: Boards with multiple directors (as well as executives who are multiple directors) hold less equity, are larger in size, and the directors' average age is slightly older. If these agency costs are significant, then reduced monitoring by multiple directors should be reflected in an inverse relation between measures of multiple directorships and subsequent firm performance.

To test this prediction of the Busyness Hypothesis, we regress firm performance in 1997 against a set of independent variables calculated as of 1995 . To control for the intensity of monitoring required by a director, we include the number of external directorships held by the firm's directors in Forbes 500 companies. The demands of serving on the board of a Forbes 500 company might be more distracting than service on the board of a smaller firm. The firm's total assets capture firm 
size, which simultaneously influences a firm's risk and its observed pattern of returns. To control for the possibility that a firm's prior success can affect its ability to attract prominent directors, we include the ratio of the firm's operating income to assets in 1995. Directors who specialize in a given industry might be less distracted by the demands of multiple directorships, so we also include an indicator variable for firms with an industry director. Equity ownership by the board and outside directors partially reflects the cost to individual directors of poor managerial oversight. Likewise, equity ownership by the CEO reflects the personal cost to him or her of the distraction of multiple directorships. Board size and percentage of independent directors have previously been found to affect board oversight.

Table V presents the results of our test of the Busyness Hypothesis. We obtain positive coefficients for both the number of directorships per director as well as the number of directorships held by outside directors. This finding, while not statistically significant, is inconsistent with the Busyness Hypothesis, which contends that the presence of multiple directors harms the firm because of their inability to provide adequate monitoring of managerial decision making. The positive coefficient for the indicator variable for executives holding multiple directorships suggests that firms are not harmed by executives with substantial external commitments. ${ }^{9}$

As a robustness test of this result, we also regress annual changes in our measures of multiple directorships against changes in the firm's operating return on assets over the two years following the change in the directorships measure. We include board size, firm size, and board ownership as control variables in these regressions. We fail to find any significant relation between our measures of multiple directors and long-term profitability in these regressions, so we do not separately report them.

\section{B. Event Study of the Effect of an Appointment of a Multiple Director}

In this part, we perform an event study of the announcement of the appointment of a multiple director to a firm's board. We construct our sample by using the 1995 proxy statements to identify the year that a specific multiple director is appointed to a board. We then search the Dow Jones Newswire to identify public announcements of the appointment of those multiple directors. We then confirm their status as multiple directors at the time of their appointment to the given firm's board using director data from Compact Disclosure. This procedure yields 291 observations of public announcements of the appointment of a multiple director from 1990 to 1995.

Table VI reports the results from an event study of the announcement of the appointment of individuals holding multiple directorships to firms' boards. The

\footnotetext{
${ }^{9}$ We also perform these regressions using: (1) only the unregulated firms in our sample, (2) an indicator variable for regulated firms, and (3) mean return on assets over the period 1993 to 1995 as a performance measure. We obtain qualitatively identical results for these sets of regressions. In addition, we simultaneously estimate firm performance and directorships from 1995 data using two-stage least squares regression. We obtain similar results.
} 


\section{TableV}

\section{Multiple Directorships and Firm Performance}

Table $V$ presents the results of our regressions between directorships and firm value. The market-to-book ratio is measured as of 1997. Directorships per director is estimated as the total number of directorships held across all the directors of a board divided by board size. Directorship per outside director is the mean number of directorships held by the firm's outside directors. This number is set to zero if the firm does not have any nonexecutives on its board. Directorships per director in Forbes 500 firms is the mean number of directorships in Forbes 500 firms. CEO is defined as the executive (including the chair) with the greatest number of directorships (usually the CEO). A firm has a CEO as a multiple director if any executive holds three or more directorships. Directorships held by highest ranking executive in Forbes 500 firms is the number of such directorships held by the executive (including the chairman of the board) with the greatest number of directorships. Total assets are those reported by Compustat at yearend. Operating margin is the firm's operating income standardized by total assets. Industry directors are defined as individuals holding three or more directorships, who hold at least 50 percent of their directorships with the same two-digit SIC code. Board ownership is the aggregate equity ownership of the firm's officers and directors. Outside board ownership is the aggregate equity ownership of the firm's outside directors. CEO ownership is the percentage equity ownership held by the executive with the largest number of directorships. If executives are tied in number of directorships, the ownership of the highest-ranking executive is included. Board size is the total number of directors appointed to the firm's board. Percent outside directors includes both independent and gray directors divided by the total number of board members. The year subscript indicates the year for which the variable is estimated. Statistical significance at the 10,5 , and 1 percent levels is indicated by ${ }^{*}, * *$, and ${ }^{* * *}$, respectively.

\begin{tabular}{|c|c|c|c|}
\hline & Market-to-Book 97 & Market-to-Book 97 & Market-to-Book $_{97}$ \\
\hline Intercept & $0.676^{* *}$ & 0.228 & -0.182 \\
\hline Directorships per director $_{95}$ & 0.068 & & \\
\hline Directorships per outside director 95 & & 0.069 & \\
\hline $\mathrm{CEO}$ is a multiple director 95 & & & 0.122 \\
\hline $\begin{array}{l}\text { Directorships per director in } \\
\text { Forbes } 500 \text { firms } 95\end{array}$ & $0.002^{* *}$ & 0.001 & \\
\hline $\begin{array}{l}\text { Directorships held by CEO in } \\
\text { Forbes } 500 \text { firms } 95\end{array}$ & & & 0.104 \\
\hline $\log$ of total assets 94 & $0.093^{* *}$ & $0.147 * * *$ & $0.106^{*}$ \\
\hline Operating margin $_{95}$ & $4.472 * * *$ & $5.212 * * *$ & $6.230 * * *$ \\
\hline Firm has an industry director & 0.070 & $0.267^{*}$ & \\
\hline $\mathrm{CEO}$ is an industry director & & & 0.285 \\
\hline Board ownership $_{95}$ & -0.001 & & \\
\hline Outside directors ownership $_{95}$ & & $0.009 *$ & $0.015^{* *}$ \\
\hline Ownership of $\mathrm{CEO}_{95}$ & & 0.000 & 0.002 \\
\hline Log of board size 95 & $0.245 * *$ & 0.130 & 0.405 \\
\hline Percent outside directors $\mathrm{S}_{95}$ & & $0.004^{*}$ & 0.004 \\
\hline Adjusted $R^{2}$ & 0.145 & 0.154 & 0.157 \\
\hline
\end{tabular}

Busyness Hypothesis predicts a negative market reaction. We find, however, positive (albeit statistically insignificant) returns for the overall sample. We also perform event studies for two subsamples of firms: (1) firms with multiple directors adding an additional multiple director to its board, and (2) firms without 
TableVI

\section{Event Period Returns of Multiple Directorship Announcements}

Table VI presents the results of an event study for days $0,+1$, with day 0 being the date of the announcement of the appointment of a multiple director. A director is considered to be a multiple director if he/she holds three or more directorships in sample firms. Announcements of multiple directorship appointments are identified from Dow Jones News Retrieval Service during the years 1990 to 1995. For each announcement, we use the directors listed in Compact Disclosure prior to the announcement and after the announcement to identify whether directors are being replaced, and if so the number of directorships held by the replaced director. If more than one director is replaced, we assume that the newly appointed director replaces the director who held the most directorships. Statistical significance at the five percent level is indicated by **.

\begin{tabular}{lccc}
\hline & All & $\begin{array}{c}\text { Announcements of an } \\
\text { Increase in the } \\
\text { Number of Multiple } \\
\text { Directors }\end{array}$ & $\begin{array}{c}\text { Announcements of a } \\
\text { Multiple Director } \\
\text { Appointment When } \\
\text { There are No Multiple } \\
\text { Directors on the Board }\end{array}$ \\
\hline $\begin{array}{l}\text { Number of firms } \\
\text { Abnormal return (days 0, }+1)\end{array}$ & 291 & 84 & 41 \\
$(t$-statistic) & $0.2 \%$ & $0.41 \%$ & $2.12 \%$ \\
\hline
\end{tabular}

multiple directors appointing a multiple director to the board for the first time. While we find positive abnormal returns for both subsamples, only the latter is statistically significant. These results suggest that market participants do not believe that the appointment of directors holding multiple board seats harms firm value.

\section{Committee Assignments}

As a more direct examination of the Busyness Hypothesis, Table VII compares the participation on board committees by directors holding three or more appointments with that of other directors holding only one or two board seats. We begin this analysis by randomly selecting 200 Forbes 500 firms and 100 non-Forbes 500 firms from our original sample and obtain data from their 1995 proxies concerning the composition of their audit, compensation, executive, nominating, and other committees. We elect to construct our subsample in this fashion because of the greater incidence of multiple directorships among larger firms. The Forbes 500 classification is a convenient manner to create subsamples reflecting firm size. We then document the number of meetings that each committee holds during a year and identify the chair of each committee. Based upon this data, we compare the participation activity by multiple directors in our random sample against directors with only one or two appointments as a further test of the quantity of monitoring provided by multiple directors.

The findings in TableVII indicate that multiple directors provide more committee service than do directors holding only one or two directorships. Multiple directors serve on more committees than do single or double directors and attend more committee meetings in total. Multiple directors also serve on the 


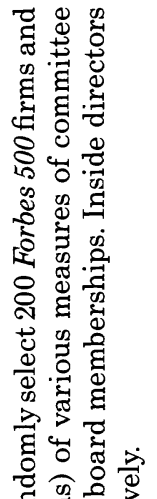

() द्वे क्टे

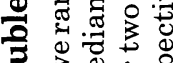

ว

定 un : "

क्ष

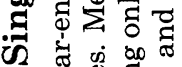

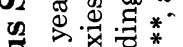

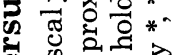

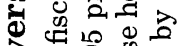

罂

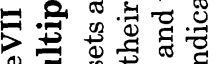

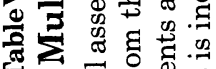

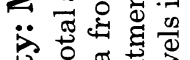

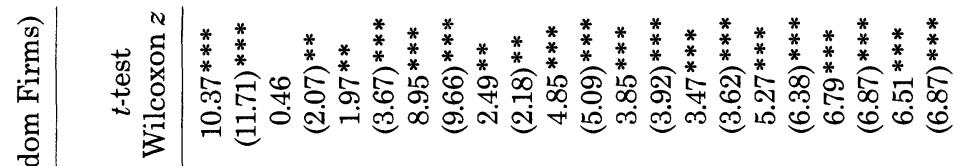

$\stackrel{0}{0}$

ล กิ

苟 茫

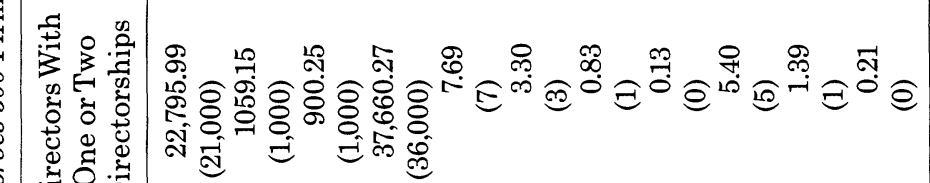
日月

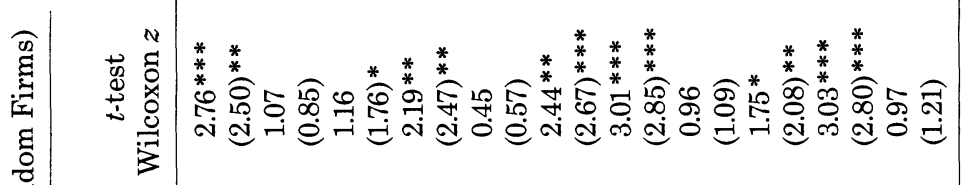

-

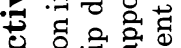

4

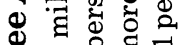

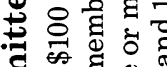

है घ

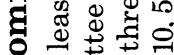

仓

声记茟

०ै

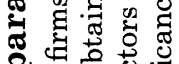

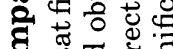

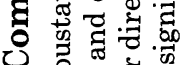

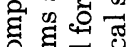

ठ द्वे क्ष

政票

है \& क

đิ

วิ

द्व

总总

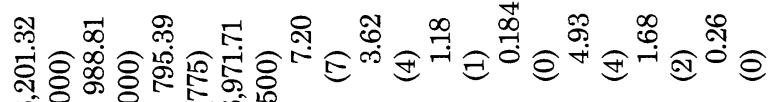

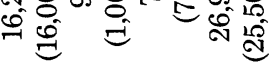

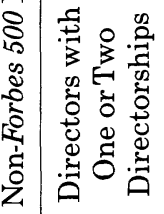

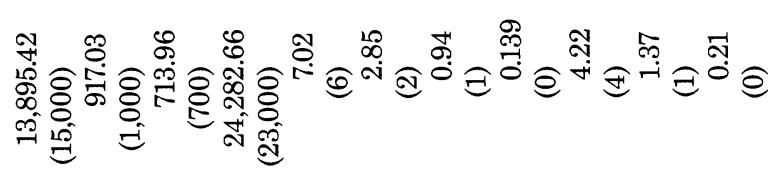

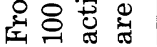

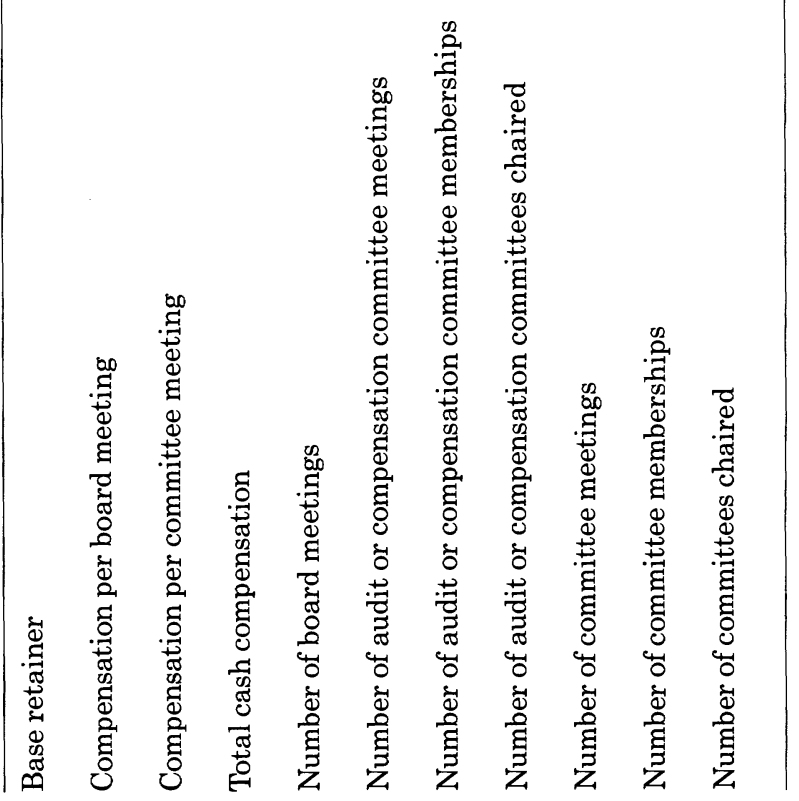


important audit and compensation committees with greater frequency and attend more of these committee meetings. Finally, we test if multiple directors accept leadership roles on these committees by serving as committee chair. We find that multiple directors chair more committees, including the audit and compensation committees, than do single or double directors.

These findings suggest that firms rely more heavily on multiple directors to provide managerial oversight and monitoring through participation on corporate governance committees. Not surprisingly, multiple directors receive greater compensation, both for committee service and overall. While the available data do not allow us to study the relative intensity of effort, we find no evidence of shirking by multiple directors. This finding is inconsistent with the predictions of the Busyness Hypothesis and the concerns of the Council of Institutional Investors about inadequate monitoring by directors holding multiple board appointments.

\section{Securities Litigation}

The Busyness Hypothesis predicts that directors holding multiple directorships will have insufficient time to monitor the firm's managers, including the accuracy of their public statements, and, more critically, the firm's financial disclosures. An active board is an important backstop for a firm's auditors in their efforts to maintain the integrity of corporate financial disclosure. Thus, the undersupervised managers of these firms are more likely to make misstatements about the firm and distort its reported results. Consequently, the Busyness Hypothesis implies that the incidence of litigation for securities fraud will be higher for those firms whose directors (particularly outside directors) hold multiple board appointments.

To test this implication of the Busyness Hypothesis we use the data set provided by the Stanford Securities Class Action Clearinghouse to identify the firms in our sample that were sued in such actions during 1996, 1997, and $1998 .{ }^{10}$ This produces a sample of 133 sued firms. ${ }^{11}$ We caution, however, that the Stanford list includes all firms sued during those years. The allegations in those complaints are untested and the firms sued have not necessarily committed the fraud alleged. We also note that the timing of the complaints is lagged; a securities fraud lawsuit filed in 1996 would typically be based on events occurring in 1994 and 1995. We do not include firms that experienced other types of litigation because that litigation can be identified only through the firm's 10 -Ks. The SEC only requires the disclosure of litigation that is material and that determination is

\footnotetext{
${ }^{10}$ http://www.securities.stanford.edu/. The Private Securities Litigation Reform Act, enacted December 22, 1995, requires plaintiffs filing securities fraud lawsuits to provide public notice of the suit at the time of filing. Consequently, data on the number of suits filed after 1995 is considerably more reliable than for past periods.

${ }^{11}$ Our sample construction excludes firms that are being sued for fraud in connection with IPOs because those companies generally would not have been required to report to the SEC prior to the public offering. IPO suits raise different legal issues, so their exclusion leaves a more homogenous sample.
} 
highly fact specific and somewhat subjective. Moreover, the claims most similar to securities fraud claims, corporate law derivative claims against officers and directors, typically would not be disclosed since the corporation is not a defendant. In addition to data reliability, the set of securities fraud claims also provides the advantage of providing a reasonably homogenous and well-studied set of claims against the firm, which allows for use of appropriate control variables.

We construct a control sample of non-sued firms to examine the role that multiple directorships might play in the likelihood of litigation against the firm. Each sued firm is matched randomly with another firm from our sample within its industry based on two-digit SIC codes.

In Panel A of Table VIII, we compare various characteristics of firms facing securities fraud lawsuits with the control sample. The differences between the samples for our measures of multiple directorships are all statistically insignificant. Directors holding multiple appointments do not appear to be overrepresented in the set of firms facing lawsuits.

In Panel B of Table VIII, we examine the impact of multiple board appointments on the likelihood of securities fraud litigation against a firm using a multivariate logistic regression. The Busyness Hypothesis predicts that multiple directorships will be positively related to the incidence of fraud because the acceptance of additional board appointments overcommits the director. Beasley (1996), for instance, reports that the number of directorships held by outside directors is positively related to instances of financial statement fraud producing SEC enforcement actions.

We include in the model other board characteristics that control for characteristics that might influence the quality of board monitoring. As previously noted, larger boards might be unwieldy, making effective monitoring of corporate managers difficult. We therefore include board size as an independent variable. The board's equity ownership is a measure of the incentive that directors have to avoid the costs of litigation since as shareholders they suffer a pro rata reduction of firm value due to any lawsuit.

We also include in the specification of our model a number of additional regressors that reflect critical elements of the firm's financial profile and can affect the likelihood that a firm will be sued for securities fraud (Francis, Philbrick, and Schipper (1994), Jones and Weingram (1996), and Johnson, Nelson, and Pritchard (2000)). Total assets reflect the firm's ability to pay a judgment or settlement and might correlate with the quality of internal controls. We include two measures of the stability of the firm's stock in the period preceding the lawsuit. Share turnover is an element in the calculation of damages for a securities fraud class action (and hence, the amount of potential attorneys' fees; Johnson et al.). In addition, prior research shows that managers of firms that experience recent performance declines might be more likely to commit fraud than those in successful firms (Arlen and Carney, (1992)). At a minimum, such firms are likely targets for plaintiffs' attorneys. Accordingly, we include the minimum one-day market-adjusted return for the year (250 trading days) prior to suit, as well as the cumulated return for that year. The standard deviation of daily returns is included to control for the 


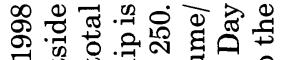

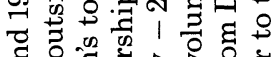
สิ 8 平 S.

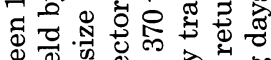
\& w 13 .

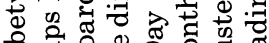
w 웡 w O की 웡 范定:

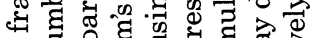
๒ . की 政 bo 당 की

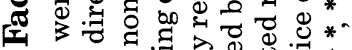
三 口 密

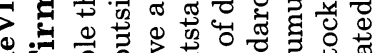
击 证

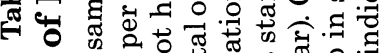
ติ

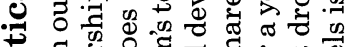

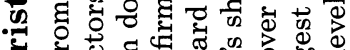
के

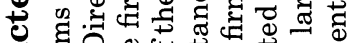
舟 영

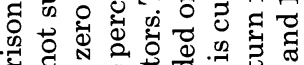

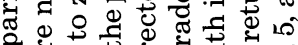

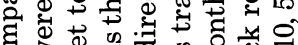

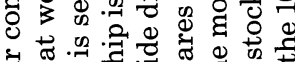
\% क 읠 또 吅

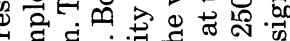
है हो ज्ञ

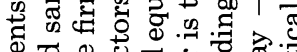
\%

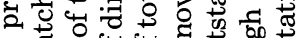

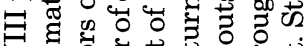

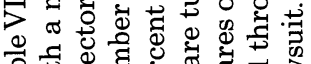

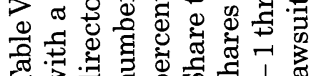

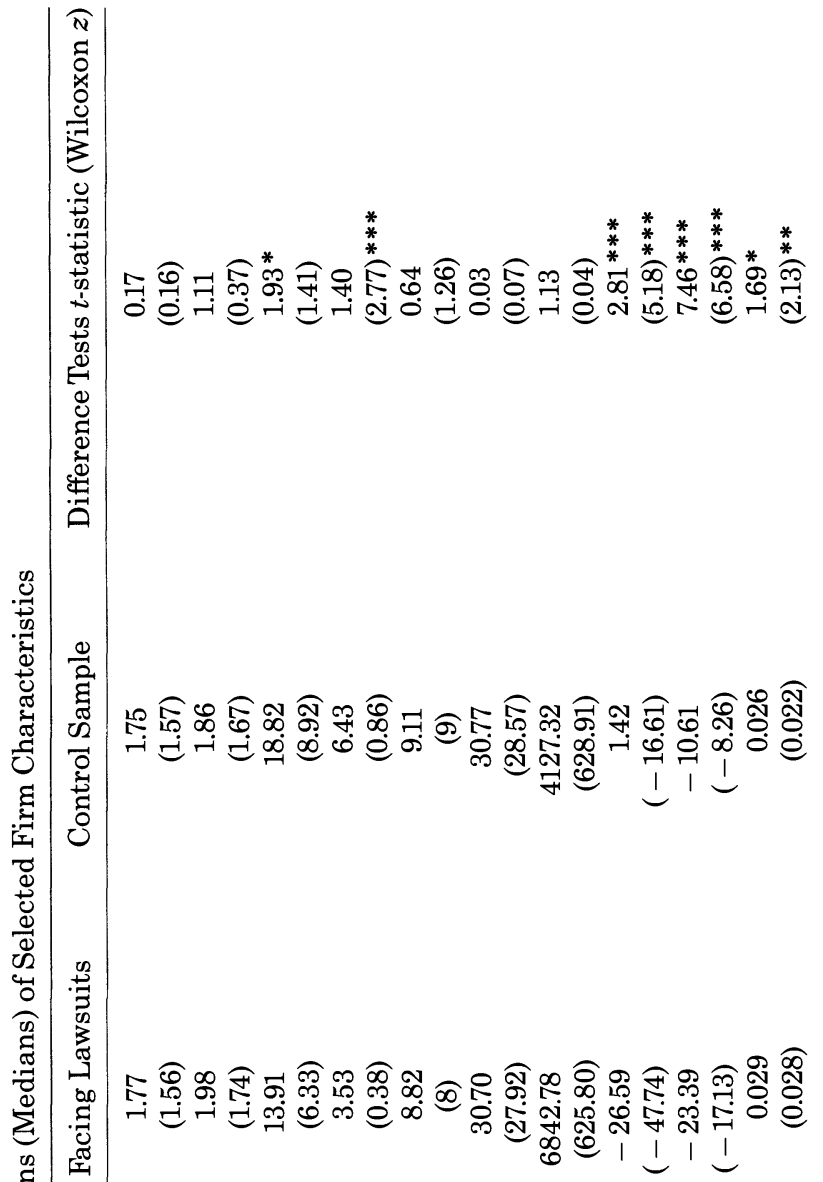

घ 空

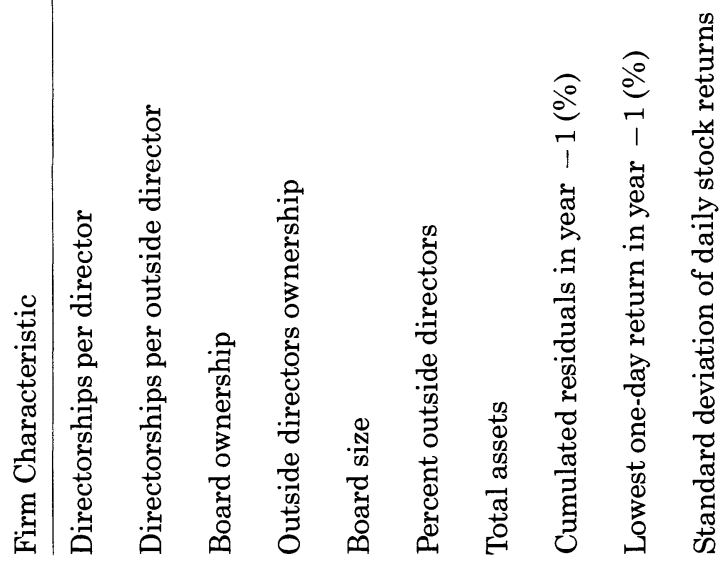




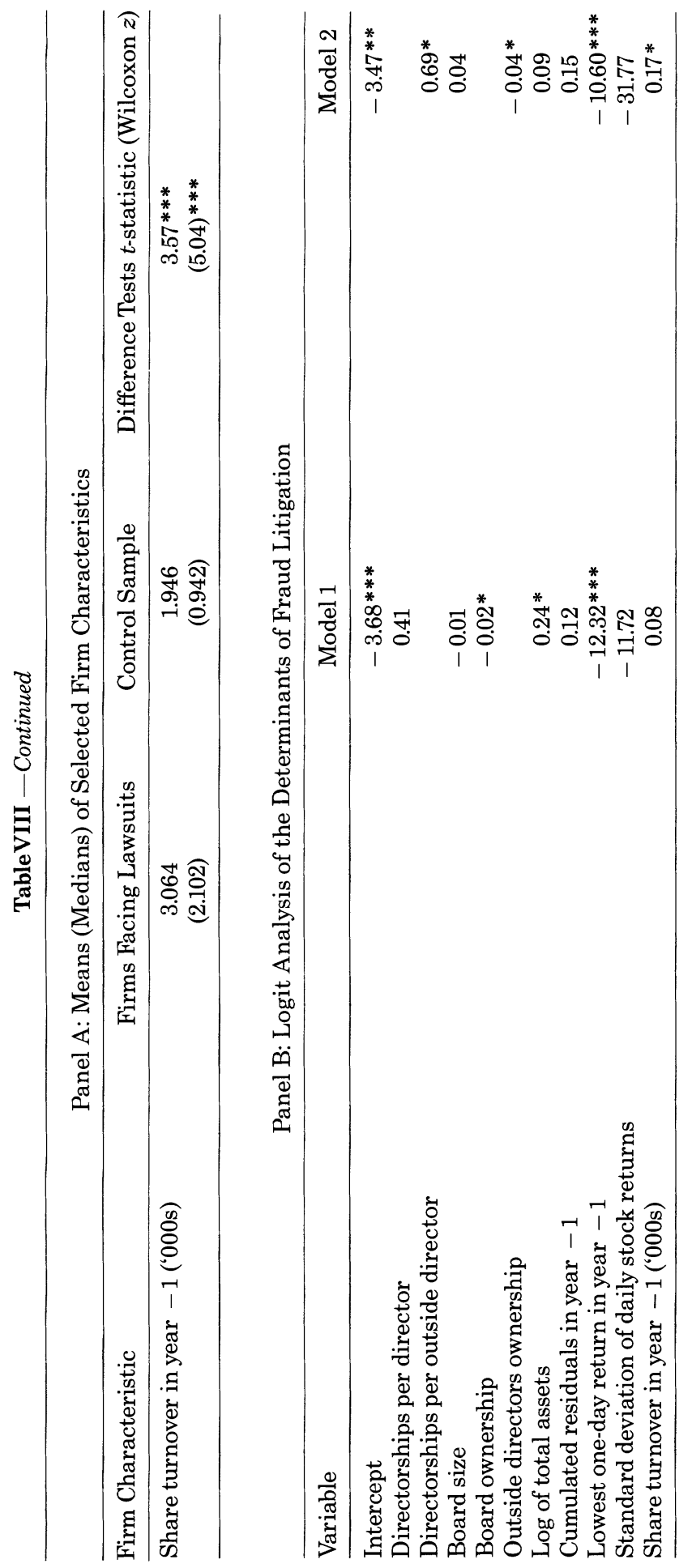


volatility of the firm's stock price. A large price drop is more likely to provoke litigation if the firm's share price is otherwise stable.

Our results are consistent with our other tests of the Busyness Hypothesis. Both the number of directorships per director and the directorships per outside director have positive coefficients as predicted by the Busyness Hypothesis, but neither is statistically significant. Other measures of multiple directorship (not reported) provide similar results. These findings offer little support to the implication of the Busyness Hypothesis that inadequate monitoring by multiple directors can lead to greater likelihood that the firm will be sued for securities fraud.

\section{E. Summary of Tests of the Busyness Hypothesis}

In sum, our tests find no correlation between service on multiple boards by a director or an executive and lower firm value. This result is inconsistent with the predictions of the Busyness Hypothesis that such service will result in ineffective board oversight. Our event study results suggest that market participants do not view the appointment of a multiple director as a negative event for the firm. We find no evidence that multiple directors serve on fewer board committees or attend fewer committee meetings than their less-busy counterparts; in fact, they sit on more committees and attend more meetings. Finally, we find no statistically significant evidence that firms with multiple directors are more vulnerable to securities fraud litigation. We conclude that the evidence does not support the proposition that multiple board memberships harm firm value.

\section{Conclusion}

This study focuses on one element affecting the quality of monitoring of corporate management by directors - the number of directorships held by directors. We find that a set of firm and individual characteristics can be used to explain the number of external directorships held by an individual, thus providing an important insight into the nature of the supply curve for board directors. Directors who serve larger firms and sit on larger boards are more likely to attract additional directorships. Multiple directors are usually older and corporate outsiders. They most commonly are executives, bankers, or consultants.

We also find that firm performance has a positive effect on the number of board seats subsequently held by a director. This finding suggests that reputation matters in the market for directors. Specifically, offers of employment as a director appear to be conditioned by the quality of previous board service as measured by the firm's financial performance. For executives, offers of board membership correlate with the performance of the firm that they manage. Thus, our results support Fama and Jensen's (1983) contention that there is a reputational effect in the market for directors.

We fail to find the negative relation predicted by the Busyness Hypothesis between the number of board memberships held by a director and subsequent firm performance. Our other tests of the Busyness Hypothesis are consistent with these results. Market participants do not react negatively to the appointment of 
a multiple director. Further, we find no evidence that multiple directors shirk their responsibilities to serve on board committees and no statistically significant evidence of a relation between multiple directorships and the likelihood that the firm will be named in a securities fraud lawsuit.

These results undermine arguments by the Council of Institutional Investors and other shareholder activists that excessive external commitments by a firm's directors can harm firm performance. The evidence presented here does not support calls by corporate governance activists for limits on the number of directorships held by any one individual.

\section{References}

Allen, William, 1992, Redefining the role of outside directors in an age of global competition, in Robert A.G. Monks and Nell Minow, eds.: Corporate Governance (Blackwell, Cambridge, MA).

Arlen, Jennifer, and William Carney, 1992, Vicarious liability for fraud on securities markets: Theory and evidence, University of Illinois Law Review, 691-711.

Beasley, Mark, 1996, An empirical analysis of the relation between the board of director composition and financial statement fraud, The Accounting Review 71, 443-465.

Bhagat, Sanjai, and Bernard Black, 1999, The uncertain relationship between board composition and firm performance, Business Lawyer 54, 921-963.

Bhagat, Sanjai, and Bernard Black, 2001, The non-correlation between board independence and longterm firm performance, Journal of Corporation Law 27, 231-274.

Bhagat, Sanjai, James Brickley, and Ronald Lease, 1985, Incentive effects of stock purchase plans, Journal of Financial Economics 14, 195-216.

Bhagat, Sanjai, Dennis Carey, and Charles M. Elson, 1999, Director ownership, corporate performance, and management turnover, Business Lawyer 54, 885-919.

Booth, James, and Daniel Deli, 1995, Factors affecting the number of outside directorships held by CEOs, Journal of Financial Economics 40, 81-104.

Brickley, James, James Linck, and Jeffrey Coles, 1999, What happens to CEOs after they retire? New evidence on career concerns, horizon problems, and CEO incentives, Journal of Financial Econom. ics 52, 341-377.

Brown, William O., Jr., and Michael T. Maloney, 1999, Exit, voice, and the role of corporate directors: Evidence from acquisition performance, Working paper, University of Virginia.

Business Roundtable, 1997, Statement on corporate governance, Washington, DC.

Core, James, Robert Holthausen, and David Larcker, 1999, Corporate governance, chief executive officer compensation, and firm performance, Journal of Financial Economics 51, 371-406.

Cotter, James, Anil Shivdasani, and Marc Zenner, 1997, Do independent directors enhance target shareholder wealth during tender offers? Journal of Financial Economics 43, 195-218.

Council of Institutional Investors, 1998, Core policies, positions and explanatory notes, Washington, DC.

Eisenberg, Theodore, Stefan Sundgren, and Martin Wells, 1997, Larger board size and decreasing firm value in small firms, Journal of Financial Economics 48, 35-54.

Fama, Eugene, and Michael Jensen, 1983, Separation of ownership and control, Journal of Law and Economics 26, 301-326.

Francis, Jennifer, David Philbrick, and Katherine Schipper, 1994, Determinants and outcomes in class action securities litigation, Working paper, Graduate School of Business, University of Chicago.

Gaver, Jennifer, Kenneth Gaver, and George Battistel, 1992, The stock market reaction to performance plan adoptions, Accounting Review 67, 172-182.

Gilson, Stuart, 1990, Bankruptcy, boards, banks and blockholders: Evidence on changes in corporate ownership and control when firms default, Journal of Financial Economics 27, 355-387.

Johnson, Marilyn F., Karen K. Nelson, and Adam C. Pritchard, 2000, In re Silicon Graphics, Inc.: Shareholder wealth effects resulting from the interpretation of the Private Securities Litigation Reform Act's pleading standard, Southern California Law Review 73, 773-810. 
Jones, Christopher L., and Seth E. Weingram, 1996, Why 10b-5 litigation risk is higher for technology and financial services firms, Working Paper No. 112, Stanford Law School.

Kaplan, Steven, and David Reishus, 1990, Outside directorships and corporate performance, Journal of Financial Economics 27, 389-410.

Korn/Ferry International, 1998, 25th Annual Board of Directors Study Los Angeles, CA.

Kumar, Raman, and Parvez Sopariwala, 1992, The effect of adoption of long-term performance plans on stock prices and accounting numbers, Journal of Financial and Quantitative Analysis 27, 561573.

Lipton, Martin, and Jay Lorsch, 1992, A modest proposal for improved corporate governance, Business Lawyer 48, 59-77.

Miwa, Yoshiro, and J. Mark Ramseyer, 2000, Corporate governance in transitional economies: Lessons from the pre-war Japanese cotton textile industry, Journal of Legal Studies 29, 171-204.

National Association of Corporate Directors, 1996, Report of the NACD blue ribbon commission on director professionalism, Washington, DC.

Shivdasani, Anil, 1993, Board composition, ownership structure and hostile takeovers, Journal of Accounting and Economics 16, 167-198.

Shivdasani, Anil, and David Yermack, 1999, CEO involvement in the selection of new board members: An empirical analysis, Journal of Finance 54, 1829-1853.

Vafeas, Nikos, 1999, Board meeting frequency and firm performance, Journal of Financial Economics $53,113-142$.

Yermack, David, 1996, A higher market valuation of companies with a small board of directors, Journal of Financial Economics 40, 185-205. 